\title{
Analysis of empathetic tendencies and conflict management strategies of teachers working abroad
}

\section{Análise de tendências empáticas e estratégias de gestão de conflitos de professores no exterior}

\section{Análise de tendências empáticas e estratégias de gestão de conflitos de professores no exterior}

\author{
Perihan Mafratoğluํ(D), Münevver Yalçinkaya²
}

\author{
${ }^{1}$ Department of Educational Management, Supervision and Planning, Near East University. Nicosia, Turkey. \\ ${ }^{2}$ Final International University. Girne, Turkey. \\ Corresponding author: \\ Perihan Mafratoğlu \\ Email: perihanmafratoglu@gmail.com.tr
}

How to cite: Mafratoğlu, P., \& Yalçinkaya, M. (2021). Analysis of empathetic tendencies and conflict management strategies of teachers working abroad. Revista Tempos e Espaços em Educação, 14(33), e16177.

http://dx.doi.org/10.20952/revtee.v14i33.16177

\begin{abstract}
In this research, empathetic tendencies and conflict management strategies of teachers that were appointed by the Ministerial Common Culture Commission to work in the Northern Cyprus Turkish Republic (TRNC) while still working in schools governed by the Republic of Turkey Ministry of National Education within the scope of overseas assignments were investigated according to various different variables. The universe of this research consists of 189 teachers working in different levels and types of schools in the TRNC. In the study, no sample selection was made, but rather it was aimed to reach the entire universe. This research is a descriptive quantitative study that has been studied with the relational scanning model. "Empathetic Tendency Scale" and "Conflict Management Strategies Scale" were used as data collection tools in the study. The research data were analyzed with SPSS Statistics 24 program, $t$ test; One Way Analysis of Variance, Tukey HSD and Pearson Correlation were applied. In the analysis of the data, the significance level was determined as .05. As a result of the research, it was determined that there is a significant difference in favor of women in terms of the gender variable in the empathetic tendency levels of the teachers working abroad. It was found that there is a significant difference in favor of teachers aged 41 and over in the compliance strategy among the conflict management strategies used by teachers. In addition, it was found that the teachers who participated in the research used the strategy of integration the most and the avoidance strategy the least; it was found that there was a significant relationship
\end{abstract}


between teachers' empathetic tendencies and strategies of integration, compromise, compliance, and domination.

Keywords: Inter-ministerial Joint Culture Commission. Foreign Teacher Assignment. Empathetic Tendency. Conflict Management.

\section{RESUMO}

Nesta pesquisa, tendências empáticas e estratégias de gestão de conflitos de professores que foram nomeados pela Comissão Ministerial de Cultura Comum para trabalhar na República Turca do Chipre do Norte (TRNC) enquanto ainda trabalhavam em escolas administradas pelo Ministério da Educação Nacional da República da Turquia em o escopo das atribuições no exterior foi investigado de acordo com várias variáveis diferentes. O universo desta pesquisa é constituído por 189 professores atuantes em diferentes níveis e modalidades de escolas do TRNC. No estudo, não foi feita uma seleção da amostra, mas sim teve como objetivo atingir todo o universo. Esta pesquisa é um estudo quantitativo descritivo que vem sendo estudado com o modelo de exploração relacional. "Escala de tendência empática" e "Escala de estratégias de gestão de conflitos" foram utilizadas como ferramentas de coleta de dados no estudo. Os dados da pesquisa foram analisados com o programa SPSS Statistics 24, teste t; Foram aplicadas a Análise de Variância One Way, Tukey HSD e Correlação de Pearson. Na análise dos dados, o nível de significância foi determinado em 0,05. Como resultado da pesquisa, constatou-se que existe uma diferença significativa a favor das mulheres em termos da variável gênero nos níveis de tendência empática dos professores que trabalham no exterior. Verificou-se que existe uma diferença significativa a favor dos professores com 41 anos ou mais na estratégia de compliance entre as estratégias de gestão de conflitos utilizadas pelos professores. Além disso, constatou-se que os professores que participaram da pesquisa utilizaram mais a estratégia de integração e menos a estratégia de evitação; constatou-se que existe uma relação significativa entre as tendências empáticas dos professores e as estratégias de integração, compromisso, adesão e dominação.

Palavras-chave: Comissão Conjunta Interministerial de Cultura. Atribuição de Professores Estrangeiros. Tendência Empática. Gestão de Conflitos.

\section{RESUMEN}

En esta investigación, las tendencias empáticas y las estrategias de manejo de conflictos de los maestros que fueron nombrados por la Comisión Ministerial de Cultura Común para trabajar en la República Turca de Chipre Septentrional (TRNC) mientras aún trabajaban en escuelas gobernadas por el Ministerio de Educación Nacional de la República de Turquía dentro de El alcance de las asignaciones en el extranjero se investigó de acuerdo con varias variables diferentes. El universo de esta investigación está conformado por 189 docentes que trabajan en diferentes niveles y tipos de escuelas en la TRNC. En el estudio, no se realizó una selección de muestra, sino que se pretendía llegar a todo el universo. Esta investigación es un estudio cuantitativo descriptivo que se ha estudiado con el modelo de barrido relacional. La "Escala de tendencia empática" y la "Escala de estrategias de gestión de conflictos" se utilizaron como herramientas de recopilación de datos en el estudio. Los datos de la investigación se analizaron con el programa SPSS Statistics 24, prueba t; Se aplicaron análisis de varianza de una vía, Tukey HSD y correlación de Pearson. En el análisis de los datos, el nivel de significancia se determinó como .05. Como resultado de la investigación, se determinó que existe una diferencia significativa a favor de las mujeres en cuanto a la variable género en los niveles de tendencia empática de los docentes que trabajan en el exterior. Se encontró que existe una diferencia significativa a favor de los docentes de 41 y más años en la estrategia de cumplimiento entre las estrategias de manejo de conflictos que utilizan los docentes. Además, se encontró que los docentes que participaron en la investigación utilizaron más la estrategia de integración y menos la estrategia de evitación; Se encontró que existía una relación 
significativa entre las tendencias empáticas de los docentes y las estrategias de integración, compromiso, cumplimiento y dominación.

Palabras clave: Comisión Mixta Interministerial de Cultura. Asignación de Docentes Extranjeros. Tendencia Empática. Manejo de Conflictos.

\section{INTRODUCTION}

As social beings, humans strive to maintain a common life together with all living things, especially other humans. As individuals continue to live their lives, they constantly communicate and engage with others. The most basic element of organizations are the individuals that make it up, and said individuals need to communicate with each other in order to achieve the goals of the organization (Gürcüoğlu \& Uyar, 2020). In this communication process, empathy is the prerequisite for a healthy communication (Güner, Güner \& Levent, 2020). Empathy, which is one of the qualities of effective communication, is defined as a person putting themself in the shoes of another person, visiting their emotional world temporarily and approaching events from their perspective (Rogers, 1975; Bellet \& Maloney, 1991).

Since empathy is an approach that focuses on understanding the events, emotions and thoughts of the other person, it can make interpersonal communication effective and easier (Kula \& Akbulut, 2020). This is because empathetic individuals tend to understand and value the perspectives and feelings of individuals belonging to groups with different cultural characteristics better than those who are not empathetic. (Bölükbaşı, 2020).

Empathetic tendency constitutes the emotional dimension of empathy and shows the individual's potential for empathy (Güner \& Levent, 2018). When we understand and empathise with the different feelings and thoughts of someone, it means that the doors of quality communication are opened (Güner, Güner \& Levent, 2020). People feel that individuals who empathise with them understand and care about them. This situation undoubtedly relaxes people and allows them to feel good. Therefore, the ability to empathise has an important role in establishing interpersonal communication (Traş \& Keser, 2019).

The rush to adapt to the changing conditions in their environment, to compete and to constantly renew, makes it inevitable for people to experience conflicts (Alıcı \& Yalçınkaya, 2019). People may get into conflicts with others in their sociological environment because of reasons such as a lack of proper communication, difference of goals, values, statuses, lives and beliefs (Yasmin \& Aleya, 2017). Therefore, it can be said that having the skills to solve the conflicts they inevitably experience in their business and social lives and to have the right management skills is a prerequisite for them to be happy, peaceful and successful (Gürcüoğlu \& Uyar, 2020).

The concept of conflict management is defined as resolving conflicts by reconciling them, and at the same time providing constructive results by directing destructive conflicts correctly (Maund, 1999). Conflict management is a different concept than its resolution, and the important thing in conflict management is to handle and manage the conflict, not to ignore and suppress it (Özdemir, 2018). In traditional approaches, the negative effects of organizational conflicts are emphasized and the belief that they are harmful to the organization and that it is always necessary to act to eliminate it is dominant (Gürcüoğlu \& Uyar, 2020). On the other hand, in modern approaches, it is said that the sources and causes of conflicts in organizations can be determined and the conflicts can be managed through them. The thought that such conflict management can contribute to the development of the organization and increase the motivation and work efficiency of employees is dominant (Özdemir, 2018).

Modern communicators find it unhealthy and inhibiting to have no conflict in the organization. They say that an organization without conflict has stagnated and is going to deteriorate (Oktay \& Yurdunkulu, 2020). 
When the literature is examined, various behavioral styles have been proposed to manage conflicts between individuals and different models have been developed to explain these styles (Çelik \& Tosun, 2019). One of the conflict management models developed in this context is "integration, avoidance, compromise, domination and compliance" (Rahim \& Bonoma, 1979). When looking at the relationship between conflict and empathy, the negative emotions of people who come into conflict with each other are revealed, so being able to manage their emotions and use their empathy skills has an important role in managing the conflict (Bilim, 2020). This is because poor communication is the root cause of interpersonal conflicts. The solution to the problems is closely related to the communication competence and empathetic tendencies of the members of the organization (Üstüner \& Kış, 2014).

Nowadays, because of interactions in basic areas such as economy, social, politics and education, people now have more intercultural contact and communication (Bölükbaşı, 2020). Accordingly, some disagreements may occur when people go outside of their usual social environment. Many factors such as the difference in the spoken language, traditions, cultural norms, dressing style and lifestyle may pave the way for some problems (Şahin, 2001). The Ministry of National Education assigns teachers to various countries in order to introduce, spread and protect Turkish culture abroad, to protect and strengthen the cultural ties of our citizens and cognates abroad, to enlighten them on religious issues and to teach the Turkish language (Karasu, 2018). For this reason, it is thought that the most important thing that teachers assigned abroad will need while representing their country is effective communication skills (Adıgüzel \& Şen, 2018). It is stated that teachers who have an empathetic perspective will be in an advantageous position in understanding individuals with different values, opinions, languages, dialects and behaviours. In short, finding solutions to problems arising from intercultural differences and developing effective communication (Bölükbaşı, 2020).

Teachers working abroad face many problems in the countries they go to (Gündoğdu, 2014). There are many sources of conflict that teachers will encounter within the school, which is a sufficiently complex organization (Külekçi Akyavuz, 2019). This situation will increase even more due to the adaptation factor to a different culture for teachers who leave the country because of their foreign duties (Akman, 2017). In this respect, it is thought that teachers' high empathetic tendencies will enable them to manage conflicts constructively and tend to permanent solutions (Msila, 2019). For this reason, it is important to investigate to what extent teachers assigned abroad have these skills and strategies. Social sustainability focuses on social relationships, interactions and human needs. For this reason, it is important to increase the quality of life in schools, to ensure social integration, and to value universal human and employee rights (Koç \& Bastas, 2019).

There are some studies that examine teachers' empathetic tendencies, conflict management strategies and the relationship between these two (Günay, 2019; Keçicioğlu, 2020; Oktay \& Yurdunkulu, 2020; Özgan, 2006). However, it is seen that there are very few studies on teachers working abroad, and these studies are aimed at determining the reasons to go abroad, the problems and job satisfaction of teachers (Akman, 2017; Gündoğdu, 2014; Karasu, 2018). In this context, it is thought that this study, which deals with the empathetic tendencies and conflict management strategies of teachers abroad who work in a different geography and culture than the country they were born and grew up in, will contribute to the literature, and will be a source for future research.

The purpose of this research is to determine the relationship between empathetic tendencies and conflict management strategies in teachers sent to the Northern Cyprus Turkish Republic (TRNC) by Turkey (TR) with the Inter-Ministerial Common Culture Commission decision. In addition, the empathetic tendencies and conflict management strategies of teachers were examined according to some variables. For this purpose, the following questions were sought in the study: 
1. In the Empathetic tendencies of the teachers working abroad; is there a significant difference according to the variables of "age, gender, branch, seniority in the profession, education level, and whether or not he/she has previously worked abroad?"

2. In the conflict management strategies of the teachers working abroad; is there a significant difference according to the variables of "age, gender, branch, seniority in the profession, education level and whether he/she has been abroad before?"

3. Is there a significant relationship between the Empathetic tendencies of teachers working abroad and their conflict management strategies?

\section{METHOD}

\section{Research Model and Sampling Selection}

This research is a descriptive quantitative study that examines the Empathetic tendencies and conflict management strategies of teachers working abroad in the TRNC. Relational scanning model, which is one of the general survey models, was used in the research. The scanning model describes the past or current situation, as it exists (Büyüköztürk et al., 2019). The universe of the research consists of 189 teachers working abroad in the TRNC in the 2019-2020 academic year, affiliated with the Ministry of National Education. The purpose of choosing a sample in a study is to gain information about that universe and to generalize. Rarely are some studies prepared to cover the entire universe on the subject. In this study, no sample selection was used, and the data were obtained by accessing the entire universe.

\section{Data Collection and Analysis}

"Empathetic Tendency Scale" developed by Dökmen (1988) and "Conflict Management Strategies Scale" developed by Özgan (2006) were used as data collection tools. In order to apply the measurement tools used in the study on the sample, the necessary permissions were obtained from the researchers who developed the scale and from the affiliated institution of the teachers. Then, all teachers were reached and the research forms were sent electronically. Four of the 174 forms that were returned were considered invalid and were not included in the analysis. The distribution of 170 teachers participating in the study according to the variables of "age, gender, branch, seniority in the profession, education level, whether he/she has worked abroad before" is as follows:

SSPS 24.0 program was used for statistical analysis. Arithmetic averages were obtained in order to measure the level of teachers' empathetic tendency and use of conflict management strategies. Statistical methods suitable for each sub-problem were used in the study. T test was used to determine the differences between demographic factors with two groups. The Levene test was used to determine whether the items with more than two groups were distributed homogeneously in terms of their answers to the questions. Since all groups were distributed homogeneously, the Anova test was used to examine whether the difference between the groups was at a significance level of .05. Tukey HSD test was applied to determine which groups differed most from others in groups where a significant difference was found.

The Cronbach alpha values in the reliability analysis for both scales was determined as .73 for the one-dimensional empathetic tendency scale. Conflict management strategies ranged from .73 for the entire scale and .53 to .79 for its sub-dimensions. These results show that both scales can be used as a reliable measurement tool in the study. In addition, it can be said that Skewness: 1.339 and Kurtosis: -.450 scores of both scales are in the range of $-1.5<X<+1.5$, hence the data show a normal distribution and parametric tests can be applied (Büyüköztürk, 2020). 


\section{RESULTS}

First, descriptive analysis of the teachers who participated in the research was made. Then, the empathetic tendency and conflict management strategies of teachers were analyzed according to demographic variables and presented in tables. As a result of the descriptive analysis, the following findings were reached: $2.4 \%(\mathrm{~N}=4)$ of the teachers participating in the study are 30 years and younger, $34.7 \%(\mathrm{~N}=59)$ are in the $31-40$ age range and $62.9 \%(\mathrm{~N}=107)$ are 41 years old or older. $22.4 \%(\mathrm{~N}=38)$ of the participants were female and $77.6 \%(\mathrm{~N}=132)$ were male; $60 \%(\mathrm{~N}=102)$ of them had undergraduate-level education and $40 \%(\mathrm{~N}=68)$ of them had graduate-level education. $17.1 \%$ $(\mathrm{N}=29)$ of the teachers were teachers of Religious Culture and Moral Knowledge, $6.5 \%(\mathrm{~N}=11)$ were Theology Vocational Lessons teacher, $14.7 \%(N=25)$ were Special Education teachers $24.7 \%(N=42)$ were counselors, $15.3 \%(\mathrm{~N}=26)$ were Technology Design teachers and $21.8 \%(\mathrm{~N}=37)$ were Vocational Lessons teachers. In terms of seniority in the profession, $11.8 \%(\mathrm{~N}=20)$ have between 510 years, $45.9 \%(\mathrm{~N}=78)$ have between $11-20$ and $42.4 \%(\mathrm{~N}=72)$ have 21 years or more. It is observed that $17.6 \%(\mathrm{~N}=30)$ of the teachers have worked abroad before and $82.4 \%(\mathrm{~N}=140)$ have not.

\section{Teachers' Levels of Empathetic Tendency and Conflict Management Strategies}

The results of the analyzes made to determine the teachers' levels of empathetic tendency and conflict management strategies are shown in tables below. Teachers' levels of empathetic tendency and use of conflict management strategies are given in Table 1: integration, avoidance, compromise, domination and compliance

Table 1. Teachers' Levels of Empathetic Tendency and Conflict Management Strategies

\begin{tabular}{ccccccccc}
\hline Scale & Factor & $\mathbf{N}$ & Min. & Max. & $\overline{\mathbf{X}}$ & SD & Value \\
\hline \multirow{2}{*}{ Empathetic } & Tendency Scale & 170 & 1,00 & 5,00 & 3,59 & .378 & High \\
\hline \multirow{3}{*}{$\begin{array}{c}\text { Conflict } \\
\text { Management } \\
\text { Strategy Scale }\end{array}$} & Integration & 170 & 1,00 & 5,00 & 4,25 & .423 & Fully \\
\cline { 2 - 9 } & Avoidance & 170 & 1,00 & 5,00 & 3,04 & .474 & Moderate \\
\cline { 2 - 9 } & Compromise & 170 & 1,00 & 5,00 & 3,83 & .431 & High \\
\cline { 2 - 9 } & Domination & 170 & 1,00 & 5,00 & 3,11 & .549 & Moderate \\
\cline { 2 - 8 } & Compliance & 170 & 1,00 & 5,00 & 3,66 & .456 & High \\
\hline
\end{tabular}

According to the results given in Table 1 , teachers gave $\bar{X}=3.59$ points to the empathetic tendency scale and stated that they have a high level of empathetic tendency. In the conflict management strategies scale, the points given by teachers are as follows: the integration factor was full level with $\bar{X}=4.25$ points, the avoidance factor was medium level with $\bar{X}=3.04$ points, the compromise factor was high level with $\bar{X}=3.83$ points, the domination factor was medium level with $\bar{X}=3.11$ points, and the compliance factor was high level with $\bar{X}=3.66$ points. According to these results, it can be said that teachers mostly use integration, compromise and compliance, and rarely avoidance and domination strategies in conflict management strategies.

\section{Teachers' Levels of Empathetic Tendency and Conflict Management Strategies According to Gender Variable}

Teachers' levels of empathetic tendency and use of conflict management strategies according to gender variable are given in Table 2: 
Table 2. Teachers' levels of Empathetic tendency and conflict management strategies according to gender variable

\begin{tabular}{|c|c|c|c|c|c|c|c|}
\hline Scale & Factor & der & $\mathbf{n}$ & $\overline{\mathbf{X}}$ & SD & $\mathbf{t}$ & $\mathbf{P}$ \\
\hline \multirow{2}{*}{\multicolumn{2}{|c|}{ Empathetic Tendency Scale }} & Female & 38 & 3,71 & .328 & \multirow{2}{*}{2,070} & \multirow{2}{*}{$.040 *$} \\
\hline & & Male & 132 & 3,56 & .386 & & \\
\hline \multirow{10}{*}{$\begin{array}{l}\text { Conflict } \\
\text { Management } \\
\text { Strategy } \\
\text { Scale }\end{array}$} & \multirow{2}{*}{ Integration Factor } & Female & 38 & 4,37 & .352 & \multirow{2}{*}{1,915} & \multirow{2}{*}{.057} \\
\hline & & Male & 132 & 4,22 & .437 & & \\
\hline & \multirow{2}{*}{ Avoidance Factor } & Female & 38 & 3,02 & .502 & \multirow{2}{*}{,- 364} & \multirow{2}{*}{.716} \\
\hline & & Male & 132 & 3,05 & .468 & & \\
\hline & \multirow{2}{*}{ Compromise Factor } & Female & 38 & 3,81 & .449 & \multirow{2}{*}{-.416} & \multirow{2}{*}{.678} \\
\hline & & Male & 132 & 3,84 & .427 & & \\
\hline & \multirow{2}{*}{ Domination Factor } & Female & 38 & 3,16 & .530 & \multirow[b]{2}{*}{.630} & \multirow[b]{2}{*}{.530} \\
\hline & & Male & 132 & 3,09 & .555 & & \\
\hline & \multirow{2}{*}{ Compliance Factor } & Female & 38 & 3,57 & .562 & \multirow{2}{*}{$-1,474$} & \multirow{2}{*}{.142} \\
\hline & & & & & & & \\
\hline
\end{tabular}

${ }^{*} \mathrm{P}<.05$

Considering the empathetic tendency levels of the teachers according to the gender variable, it is seen that there is a significant difference in favor of female teachers $(t=2.070, P<.5)$. It was found that females have $\overline{\mathrm{X}}=3.71$, and males $\overline{\mathrm{X}}=3.56$.

According to the data in Table 2, it is seen that there is no significant difference between men and women in any factor of the conflict management strategies scale. Findings in these factors are as follows: integration: $\mathrm{t}=1.915, \mathrm{P}>.5$; avoidance: $\mathrm{t}=-. .364, \mathrm{P}>.5$; compromise: $\mathrm{t}=-. .416, \mathrm{P}>.5$; domination: $t=.630, P>.5$; compliance: $t=-1.474, P>.5$.

\section{Levels of Empathetic Tendency and Use of Conflict Management Strategies of Teachers by Age Variable}

Teacher's levels of empathetic tendency and use of conflict management strategies according to the age variable are given in Table 3:

Table 3. Teachers' Levels of Empathetic Tendency and Use of Conflict Management Strategies by Age Variable

\begin{tabular}{|c|c|c|c|c|}
\hline Scale & Factor & Anova & $\mathbf{P}$ & Groups with a Difference \\
\hline Empathetic Tendency S & & .608 & .508 & - \\
\hline \multirow{5}{*}{$\begin{array}{l}\text { Conflict Management } \\
\text { Strategy Scale }\end{array}$} & Integration & 1,539 & .218 & - \\
\hline & Avoidance & 1,294 & .277 & - \\
\hline & Compromise & 2,605 & .077 & - \\
\hline & Domination & .347 & .707 & - \\
\hline & Compliance & 5,713 & $.004^{* *}$ & $31-40<41+$ \\
\hline
\end{tabular}

$* * P<.01$

According to the data in Table 3, it is seen that the age variable does not cause a significant difference in teachers' empathetic tendency levels $(\mathrm{F}=.608, \mathrm{P}>.5)$. When we look at the scale of conflict management strategies, there is no significant difference between the groups in the first four factors (integration: $\mathrm{F}=1.539, \mathrm{P}>.5$; avoidance: $\mathrm{F}=1.294, \mathrm{P}>.5$; compromise: $\mathrm{F}=2.605, \mathrm{P}>.5$; domination: $F=.347, P>.5$ ). However, it was determined that there was a significant difference between the groups in the compliance factor $(\mathrm{F}=-5.713, \mathrm{P}<.1)$. According to the results of the Tukey HSD test applied to determine which groups have the most significant difference, it was determined 
that teachers between the ages of $31-40(\bar{X}=3,54)$ used the compliance strategy significantly less than those aged 41 and over $(\overline{\mathrm{X}}=3,75)$.

\section{Levels of Empathetic Tendency and Use of Conflict Management Strategies of Teachers According} to the Branch Variable

Teachers' levels of empathetic tendency and use of conflict management strategies according to the branch variable are given in Table 4:

Table 4. Teachers' Levels of Empathetic Tendency and Use of Conflict Management Strategies According to the Branch Variable

\begin{tabular}{|c|c|c|c|c|}
\hline Scale & Factor & Anova & $\mathbf{P}$ & Groups with a Difference \\
\hline Empathetic Tendency $\subseteq$ & & .586 & .711 & - \\
\hline \multirow{5}{*}{$\begin{array}{l}\text { Conflict Management } \\
\text { Strategy Scale }\end{array}$} & Integration & 1,196 & .313 & - \\
\hline & Avoidance & 1,131 & .346 & - \\
\hline & Compromise & .823 & .535 & - \\
\hline & Domination & .908 & .477 & - \\
\hline & Compliance & .564 & .728 & - \\
\hline
\end{tabular}

According to the data in Table 4, it was determined that the branch variable did not cause any significant difference at both the empathetic tendency levels of teachers ( $F=.586, P>.5)$ and their usage of conflict management strategies (integration: $F=1.196, P>.5$; avoidance: $F=1.131, P>.5$; compromise: $\mathrm{F}=.823, \mathrm{P}>.5$; domination: $\mathrm{F}=.908, \mathrm{P}>.5$; compliance: $\mathrm{F}=.564, \mathrm{P}>.5$ ).

\section{Levels of Empathetic Tendency and Use of Conflict Management Strategies of Teachers According to the Seniority Variable}

Teachers' levels of empathetic tendency and conflict management strategy usage according to the seniority variable are given in Table 5:

Table 5. Teachers' Levels of Empathetic Tendency and Use of Conflict Management Strategies According to the Seniority Variable

\begin{tabular}{lllll}
\hline Scale & Factor & Anova & $\mathbf{P}$ & Groups with a Difference \\
\hline Empathetic Tendency & Scale & 2,485 & .086 & - \\
\hline \multirow{3}{*}{$\begin{array}{l}\text { Conflict Management } \\
\text { Strategy Scale }\end{array}$} & \multicolumn{1}{c}{ Integration } & 2,054 & .131 & - \\
\cline { 2 - 5 } & Avoidance & .287 & .751 & - \\
\cline { 2 - 5 } & Compromise & .157 & .855 & - \\
\cline { 2 - 5 } & Domination & .244 & .784 & - \\
\cline { 2 - 5 } & Compliance & 2,977 & .054 & - \\
\hline
\end{tabular}

According to the data in Table 5, the seniority variable was found to not cause a significant difference in neither the empathetic tendency levels of teachers $(F=2.485, P>.5)$ nor their use of conflict management strategies (integration: $\mathrm{F}=2.054, \mathrm{P}>.5$; avoidance: $\mathrm{F}=.287, \mathrm{P}>.5$; compromise: $F=.157, P>.5$; domination: $F=.244, P>.5$; compliance: $F=2.977, P>.5)$.

\section{Levels of Empathetic Tendency and Using Conflict Management Strategies of Teachers According to the Educational Status Variable}

Teachers' levels of empathetic tendencies and use of conflict management strategies according to the educational status variable are given in Table 6: 
Table 6. Teachers' Levels of Empathetic Tendency and Use Of Conflict Management Strategies According to the Educational Status Variable

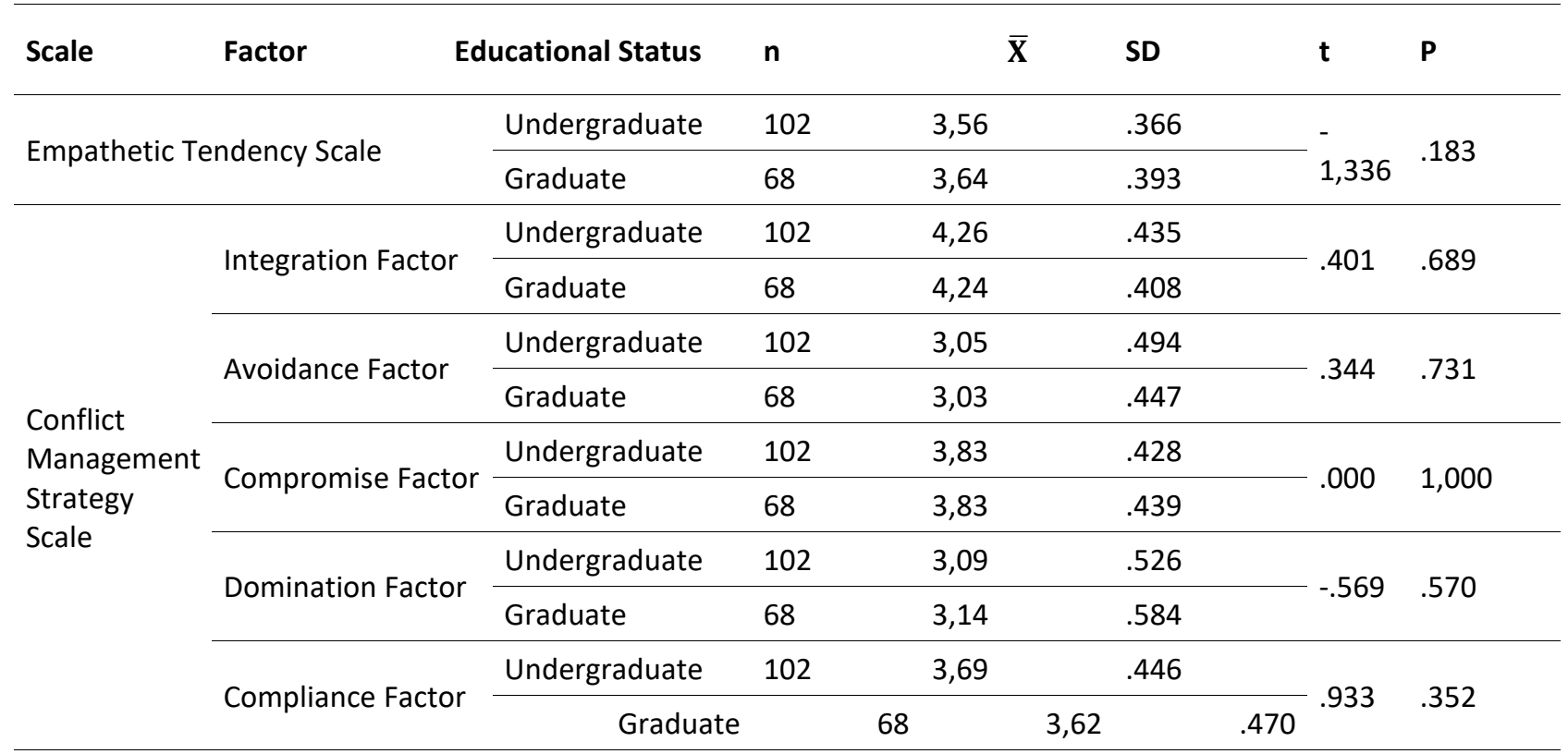

According to the data in Table 6, educational status was found to not cause a significant difference in neither the empathetic tendency levels of teachers ( $t=-1.336, P>.5)$ nor their usage of conflict management strategies (integration: $t=.401, P>.5$; avoidance: $t=.344, P>.5$; compromise: $\mathrm{t}=.000, \mathrm{P}>.5$; domination: $\mathrm{t}=-. .569, \mathrm{P}>.5$; compliance: $\mathrm{t}=.933, \mathrm{P}>.5$ ).

\section{Teachers' Levels of Empathetic Tendency and Use of Conflict Management Strategies According to the Previous Overseas Work Experience Variable}

Teachers' levels of empathetic tendency and use of conflict management strategies according to the previous overseas work experience variable are given in Table 7:

Table 7. Teachers' Levels of Empathetic Tendency and Use of Conflict Management Strategies According to the Previous Overseas Work Experience Variable

\begin{tabular}{|c|c|c|c|c|c|c|c|}
\hline Scale & Factor & reviously worked abroad & $\mathbf{n}$ & $\overline{\mathbf{X}}$ & SD & $\mathbf{t}$ & $\mathbf{P}$ \\
\hline \multirow{2}{*}{\multicolumn{2}{|c|}{ Empathetic Tendency Scale }} & Yes & 30 & 3,65 & .382 & \multirow{2}{*}{.935} & \multirow{2}{*}{.351} \\
\hline & & No & 140 & 3,58 & .377 & & \\
\hline \multirow{10}{*}{$\begin{array}{l}\text { Conflict } \\
\text { Management } \\
\text { Strategy Scale }\end{array}$} & \multirow[b]{2}{*}{ Integration Factor } & Yes & 30 & 4,20 & .392 & \multirow[b]{2}{*}{-.694} & \multirow[b]{2}{*}{.489} \\
\hline & & No & 140 & 4,26 & .431 & & \\
\hline & \multirow[b]{2}{*}{ Avoidance Factor } & Yes & 30 & 3,01 & .416 & \multirow[b]{2}{*}{-.402} & \multirow[b]{2}{*}{.689} \\
\hline & & No & 140 & 3,05 & .487 & & \\
\hline & \multirow{2}{*}{$\begin{array}{l}\text { Compromise } \\
\text { Factor }\end{array}$} & Yes & 30 & 3,74 & .349 & \multirow[b]{2}{*}{$-1,295$} & \multirow[b]{2}{*}{.197} \\
\hline & & No & 140 & 3,85 & .445 & & \\
\hline & \multirow[b]{2}{*}{ Domination Factor } & Yes & 30 & 3,17 & .552 & \multirow[b]{2}{*}{.653} & \multirow[b]{2}{*}{.515} \\
\hline & & No & 140 & 3,10 & .549 & & \\
\hline & \multirow{2}{*}{ Compliance Factor } & Yes & 30 & 3,70 & .314 & \multirow{2}{*}{.404} & \multirow{2}{*}{.687} \\
\hline & & No & 140 & 3,66 & .481 & & \\
\hline
\end{tabular}


According to the data in Table 7, whether or not they had worked abroad before was determined to not cause a significant different in neither the empathetic tendency levels of the teachers ( $t=.935, P>.5)$ nor their usage of conflict management strategies (integration: $t=-.694$; avoidance: $t=-.402, P>.5$; compromise: $t=-1.295, P>.5$; domination: $t=.653, P>.5$; compliance: $\mathrm{t}=.404, \mathrm{P}>\mathrm{.5}$ ).

\section{The Relationship between Teachers' Levels of Empathetic Tendency and Their Usage of Conflict Management Strategies}

The correlation results made to determine whether if there is a relationship between the empathetic tendencies of teachers and their usage of conflict management strategies or not are presented in Table 8:

Table 8. Relationship between Teachers' Levels of Empathetic Tendencies and Their Usage of Conflict Management Strategies

\begin{tabular}{|c|c|c|c|c|c|c|c|}
\hline & & $\begin{array}{l}\text { Empathetic } \\
\text { Tendency } \\
\text { Scale }\end{array}$ & $\begin{array}{l}\text { Integration } \\
\text { Factor }\end{array}$ & $\begin{array}{l}\text { Avoidance } \\
\text { Factor }\end{array}$ & $\begin{array}{l}\text { Compromise } \\
\text { Factor }\end{array}$ & $\begin{array}{l}\text { Domination } \\
\text { Factor }\end{array}$ & $\begin{array}{l}\text { Compliance } \\
\text { Factor }\end{array}$ \\
\hline \multirow{2}{*}{$\begin{array}{l}\text { Empathetic } \\
\text { Tendency } \\
\text { Scale }\end{array}$} & $\begin{array}{l}\text { Pearson } \\
\text { Correlation }\end{array}$ & 1 & $.340^{* *}$ & .008 & $.194^{*}$ & $.180^{*}$ & $.204^{* *}$ \\
\hline & Sig. (2-tailed) & & .000 & .913 & .011 & .019 & .008 \\
\hline \multirow{2}{*}{$\begin{array}{l}\text { Integration } \\
\text { Factor }\end{array}$} & $\begin{array}{l}\text { Pearson } \\
\text { Correlation }\end{array}$ & $.340^{* *}$ & 1 & .064 & $.496^{* *}$ & .141 & $.286^{* *}$ \\
\hline & Sig. (2-tailed) & .000 & & .410 & .000 & .066 & .000 \\
\hline \multirow{2}{*}{$\begin{array}{l}\text { Avoidance } \\
\text { Factor }\end{array}$} & $\begin{array}{l}\text { Pearson } \\
\text { Correlation }\end{array}$ & .008 & .064 & 1 & $.428^{* *}$ & -.021 & $.484^{* *}$ \\
\hline & Sig. (2-tailed) & .913 & .410 & & .000 & .785 & .000 \\
\hline \multirow{2}{*}{$\begin{array}{l}\text { Compromise } \\
\text { Factor }\end{array}$} & $\begin{array}{l}\text { Pearson } \\
\text { Correlation }\end{array}$ & $.194^{*}$ & $.496^{* *}$ & $.428^{* *}$ & 1 & .032 & $.618^{* *}$ \\
\hline & Sig. (2-tailed) & .011 & .000 & .000 & & .677 & .000 \\
\hline \multirow{2}{*}{$\begin{array}{l}\text { Domination } \\
\text { Factor }\end{array}$} & $\begin{array}{l}\text { Pearson } \\
\text { Correlation }\end{array}$ & $.180^{*}$ & .141 & -.021 & .032 & 1 & .028 \\
\hline & Sig. (2-tailed) & .019 & .066 & .785 & .677 & & .713 \\
\hline \multirow{2}{*}{$\begin{array}{l}\text { Compliance } \\
\text { Factor }\end{array}$} & $\begin{array}{l}\text { Pearson } \\
\text { Correlation }\end{array}$ & $.204^{* *}$ & $.286^{* *}$ & $.484^{* *}$ & $.618^{* *}$ & .028 & 1 \\
\hline & Sig. (2-tailed) & .008 & .000 & .000 & .000 & .713 & \\
\hline$N$ & & 170 & 170 & 170 & 170 & 170 & 170 \\
\hline
\end{tabular}

${ }^{*} \mathrm{P}<.05 ;{ }^{* * \mathrm{P}<.01}$

According to the correlation results given in Table 8, it was found that there is a significant relationship between the levels of empathetic tendency and usage of the integration strategy $(r=.340, p<.01)$. No significant relationship between teachers' empathetic tendencies and their usage of the avoidance strategy were observed $(r=.008, p>.05)$. It is seen that there is a significant relationship between the empathetic tendencies of the teachers participating in the study and the usage of the compromise strategy $(r=.194, p<.05)$. It is seen that there is a significant relationship between teachers' empathetic tendencies and the usage of the domination strategy $(r=.180, p<.05)$. It is seen that there is a significant relationship between the empathetic tendency levels of the participants and the usage of the compliance strategy $(r=.204, p<.01)$. 


\section{DISCUSSION}

In this study, which examines the empathetic tendencies and levels of conflict management strategy usage of teachers working abroad in the TRNC, it has been determined that the teachers have a high level of empathetic tendency. It was also found that teachers evaluated the integration factor of the conflict management strategies scale at full level, compromise and compliance factors at high level, and avoidance and domination factors at medium level. According to these results, it can be said that teachers mostly use integration, compromise and compliance, and rarely use avoidance and domination strategies in conflict management. It can be said that the reason for this is that teachers are highly interested in the interests of both themselves and their colleagues, and they show empathy to the other party. It can also be concluded that they concentrate on producing successful solutions for good communication and future interaction, keeping the relationship within the rules of courtesy. In the research of Özdemir (2018) and Külekçi Akyavuz (2019), it was found that among the conflict management styles, teachers mostly used the integration style, followed by the strategies of compromise, compliance and avoidance, and finally dominance. They also state that teachers do not only try to solve the problem according to their own goals and interests, but also take into account the wishes and interests of the other party. In the study conducted by Altınay, Dağlı, and Altınay (2016), it is underlined that the cooperation of teachers is important in managing the conflicts in schools in order to gain reciprocity.

In the study, it was determined that while the gender variable caused differentiation in the empathetic tendency levels of teachers, it did not cause a significant difference in their use of conflict management strategies. When the studies conducted are examined, regardless of a significant difference in empathy levels according to the gender variable, it is seen that the empathy scores of women are higher than the empathy scores of men. Güner \& Levent (2018) found that the empathetic tendencies of women were higher than men in their research on teachers. Dökmen (2018) associates women's higher empathetic tendencies compared to men with female sensitivity. According to Hançer and Tanrıverdi (2003), the fact that women's empathetic tendencies are higher than men is due to their social skills coming to the fore. Silkü and Yalçınkaya (2008) revealed that there is no statistically significant difference between the conflict management methods the used by the participants according to the gender variable. According to Uysal (2012) however, there is a significant difference in the factors of avoiding conflict management strategies, reconciliation and compliance by gender. She found that male teachers used the avoidance, reconciliation and compliance strategies more. Özgan (2006) found in his study that there was a significant difference in the domination and compliance strategies in favor of men and attributed this finding to the use of domination strategies depending on the gender roles of men.

It was determined that the age variable did not cause a significant difference in empathetic tendency levels. The reason for the lack of a significant difference between age groups can be shown as the fact that the teachers who were sent to work abroad were selected by being subjected to some special exams and they have a certain cognitive and affective background. Keçicioğlu (2020) and Günay (2019) stated in their research that the age variable does not cause a difference in teachers' empathetic tendencies. Güner \& Levent (2018) stated in their study that the empathetic tendencies of teachers between the ages of 30-40 are higher than those under the age of 30 . It was determined that the age variable caused a significant difference in the adaptation factor, which is the last factor of the conflict management strategies scale. Accordingly, it was determined that teachers between the ages of 31-40 use the compliance strategy significantly less than those over the age of 41 . The reason for this can be said to be the life experience of teachers in the age group 41 and above. In the study conducted by Yaman and Türker (2011), it was found that the age variable creates a significant difference in the adaptation factor.

It is seen that the branch variable does not cause a significant difference in neither the empathetic tendency levels of the teachers nor their usage of conflict management strategies. The 
reason for this can be attributed to the fact that all teachers have an empathetic perspective and have more empathetic tendencies than other professions in order to teach their students empathy. Gürsel (2016) concluded in his study that the branch variable did not create a significant difference in teachers' empathetic tendencies. In the study conducted by Şener (2019), it was found that there was no significant difference in the branch variable in conflict management strategies. Oktay \& Yurdunkulu (2016) found in their study that Turkish and Social Studies teachers used the integration strategy less than teachers of other branches.

It is seen that the variable of seniority does not cause a significant difference in neither the empathetic tendency levels of teachers nor their usage of conflict management strategies. Gürsel (2016) concluded in his study that the seniority variable does not make a significant difference in teachers' empathetic tendencies. Güner \& Levent (2018), on the other hand, concluded in their study that the empathetic tendency levels of the group with between 4-10 years' worth of time spent in the profession is significantly lower than that of other groups'.

It is seen that the educational status variable does not cause a significant difference in neither the empathetic tendency levels of the teachers nor their usage of conflict management strategies. Oktay \& Yurdunkulu (2016) could not find a significant difference in conflict management strategies of teachers according to their educational status, but Özgan (2006) concluded that teachers with undergraduate education use the integration strategy more than teachers with graduate education.

It is seen that whether or not they have worked abroad before does not cause a significant difference in neither the empathetic tendency levels of the teachers nor their usage of conflict management strategies. Akman (2017), in his research on the problems of teachers working abroad, concluded that teachers who were assigned abroad for the first time felt lonely during the process of getting used to their duties abroad, faced some problems in the countries they went to, and were depressed during the adaptation process. Florin, et.al.(2020) underlines the importance of lifelong learning to cope up with those societal problems.

According to the correlation results made to measure the relationship between teachers' empathetic tendencies and their usage of conflict management strategies, it was found that there is a significant relationship between their empathetic tendencies and the usage of the integration, compromise, domination and compliance strategies. However, it was determined that there was no significant relationship between empathetic tendencies and the usage of the avoidance strategy. Accordingly, it can be said that those who have high empathetic tendencies are individuals who have the ability to understand the other side and look at the events from their point of view, and they can solve problems effectively and permanently by using these features in emerging conflicts (Karaman, 2018). In previous studies, it has been stated that the consistency and quality of relationships between teachers is one of the reasons for high organizational trust (Koç, 2019), as a result of which there is less conflict. It is known that individuals with a high perception of communication competence prefer integration and reconciliation strategies more in situations of conflict (McKinney \& Kelly, 2009).

\section{CONCLUSION AND RECOMMENDATIONS}

In this study, which examines the empathetic tendencies and use of conflict management strategies of teachers working abroad in the TRNC, it has been determined that the teachers have a high level of empathetic tendency. It was found that teachers evaluated the integration factor of the conflict management strategies scale at full level, compromise and compliance factors at high level and avoidance and domination factors at medium level. According to these results, it can be said that teachers mostly use integration, compromise and compliance, and rarely use the avoidance and domination strategies from the conflict management strategies. 
Considering the empathetic tendency levels of the teachers working abroad, there is a significant difference in favor of female teachers according to the gender variable; it was found that there was no significant difference according to age, branch, seniority in the profession, educational status and whether if they had worked abroad or not.

Considering the conflict management strategies of the teachers working abroad, there is a significant difference in favor of teachers over the age of 40 only in terms of the age variable. However, it was concluded that there is no significant difference according to the variables of gender, branch, seniority in the profession, education status and whether if they have worked abroad or not.

There is a significant relationship between the empathetic tendencies of the teachers working abroad and the strategies of integration, compromise, domination and compliance; it was determined that there was no significant relationship between the aforementioned empathetic tendencies and the avoidance strategy.

In line with these results, it can be suggested that practitioners should be given training in communication and empathy skills to improve the empathetic tendency levels of teachers who will be sent abroad. In addition, according to the research findings, it was observed that teachers used avoidance and domination strategies at a medium level. However, teachers are expected not to choose these two strategies in effective conflict management. It is extremely important for teachers working abroad to be able to manage the conflict situations they will encounter in the most appropriate way. For this reason, teachers can be trained on conflict management prior to their assignment so that effective communication can take place during their assignment abroad.

For the researchers, by expanding the sample of this study, it can be suggested that they should conduct a more comprehensive study with the mixed method, including the topics and people they experience conflicts with and about, aimed at all teachers working abroad. When the literature is examined, it is seen that there are very few studies on teachers working abroad. Therefore, studies can be conducted to determine the communication competencies of the teachers working abroad, their cultural sensitivity, their social and emotional intelligence levels, their job satisfaction and their adaptation processes to the education systems of the countries they have gone to.

It has been observed that there are very few studies in the literature dealing with the empathetic tendencies of branch teachers and their usage of conflict management strategies. Studies can be conducted especially for Vocational Lessons teachers, Technology Design teachers, Counselor teachers and Religious Culture and Moral Knowledge teachers working in high schools.

Authors' Contributions: Perihan Mafratoğlu: conception and design, acquisition of data, analysis and interpretation of data, drafting the article, critical review of important intellectual content. Münevver Yalçinkaya: conception and design, acquisition of data, analysis and interpretation of data, drafting the article, critical review of important intellectual content. All authors have read and approved the final version of the manuscript.

Ethics Approval: Not applicable.

Acknowledgments: Not applicable.

\section{REFERENCES}

Adıgüzel, F. B., \& Şen, Ü. (2018). Türkçe ve Türk kültürü dersi öğretmenlerinin yurt dışı görevlerine ilişkin kaygı ve hazırbulunuşluk durumları. Trakya Eğitim Dergisi, 8(4), 822-839. https://doi.org/10.24315/trkefd.31657

Alıcı, B., \& Yalçınkaya, M. (2019). Öğretmenlerin mesleki doyum ve örgütsel bağlılık düzeylerinin iş stresi düzeylerine göre incelenmesi. Folklor/Edebiyat, 25(97), 213-229. https://doi.org/10.22559/folklor.939

Altinay, F., Dagli, G., \& Altınay, Z. (2017). Role of technology and management in tolerance and reconciliation education. Quality \& Quantity, 51(6), 2725-2736. https://doi.org/10.1007/s11135-016-0419-x 
Akman, Y. (2017). Milli Eğitim Bakanlığı yurtdışı teşkilatında görev yapan öğretmenlerin sorunları. Ege Eğitim Dergisi, 18 (1) , 345-375. https://doi.org/10.12984/egeefd.285294

Bellet, P. S., \& Maloney, M. J. (1991). The importance of empathy as an interviewing skill in medicine. Jama, 266(13), 1831-1832.

Bilim, H. G. (2020). Yöneticilerin duygusal zekâ seviyelerinin kullandıkları çatışma yönetim stillerine etkisi. Hacettepe Üniversitesi Sosyal Bilimler Dergisi, 2 (2) , 189-209.

Bölükbaşı, A. (2020). Öğretmen adaylarının kültürlerarası duyarlılıklarının empatik eğilim, öznel iyi oluş ve sosyodemografik değişkenler açısından incelenmesi. Mersin Üniversitesi Eğitim Fakültesi Dergisi, 16(1), 44-62.

https://doi.org/10.17860/mersinefd.640893

Büyüköztürk, Ş. (2020). Sosyal bilimler için veri analizi kitabı (27. bs). Pegem Akademi Yayıncılık.

Büyüköztürk, Ş., Kılıç Çakmak, E., Erkan Akgün, Ö., Karadeniz, Ş., \& Demirel, F. (2019). Bilimsel araştırma yöntemleri (27. bs). Pegem Akademi Yayıncılık. https://doi.org/10.14527/9789944919289

Çelik, K., \& Tosun, A. (2019). The relationship between school administrators' conflict management styles and organizational health. Adıyaman Üniversitesi Eğitim Bilimleri Dergisi, 9(1), 99-121.

https://doi.org/10.17984/adyuebd.456709

Dökmen, Ü. (1988). Empatinin yeni bir modele dayanarak ölçülmesi ve psikodrama ile geliştirilmesi. Ankara University Journal of Faculty of Educational Sciences (JFES), 21(1), 155-190. DOI: 10.1501/Egifak_0000000999

Dökmen, Ü. (2018). Sanatta ve günlük yaşamda iletişim çatışmaları ve empati (61. bs), Remzi Kitabevi.

Florin, K., Hedlund, E., \& Åkerblom, E. (2020). Lifelong Learning for All!. Mediterranean Journal of Social \& Behavioral Research, 4(2), 35-39. https://doi.org/10.30935/mjosbr/9599

Günay, M. (2019). Beden eğitimi öğretmenlerinin empatik eğilimleri ile öğrencilerinin öğretmene yönelik yakınlık algısı arasındaki ilişkinin incelenmesi. Yayımlanmamış Yüksek Lisans Tezi. Marmara Üniversitesi. İstanbul.

Gündoğdu, Y. (2014). Suudi Arabistan Türk okullarında görev yapan öğretmenlerin sorunları. Milli Eğitim Dergisi, 44(201), 125-148.

Güner, A., Güner, Z. \& Levent, A. F. (2020). Kültürler arası duyarlılık ve empatik eğilimler: bir derleme çalışması, Avrasya Sosyal ve Ekonomi Araştırmaları Dergisi (ASEAD), 7(10), 259-277.

Gürsel, H. E. (2016). Branş öğretmenlerinin empatik eğilim düzeylerinin çeşitli değişkenler açısından incelenmesi (Avcılar örneği). Yayımlanmamış Yüksek Lisans Tezi. İstanbul Aydın Üniversitesi, İstanbul.

Güner, A., \& Levent, A. F. (2018). Öğretmenlerin kültürler arası duyarlılık düzeyleri ile empatik eğilimleri arasındaki ilişki: Halk eğitimi merkezi örneği. Journal of International Scientific Researches, 3(2), 968-984.

https://doi.org/10.21733/ibad.471381

Gürcüoğlu, S., \& Uyar, M. (2020). Örgütsel çatışma ile örgütsel iklim arasındaki ilişki. Balıkesir Üniversitesi Sosyal Bilimler Enstitüsü Dergisi, 23(43), 229-254. https://doi.org/10.31795/baunsobed.682198

Hançer, M. \& Tanrısevdi, A. (2003). Sosyal zeka kavramının bir boyutu olarak empati ve performans üzerine bir inceleme. Cumhuriyet Üniversitesi Sosyal Bilimler Dergisi, 27 (2), 211-225.

Karaman, F. (2018). Almanca öğretmen adaylarının empatik eğilim düzeyi. Batman Üniversitesi Yaşam Bilimleri Dergisi, 8(1), 52-57.

Karasu, M. (2018). MEB tarafından yurt dışına görevlendirilen öğretmenlerin gidiş nedenleri. Gümüşhane Üniversitesi Sosyal Bilimler Enstitüsü Elektronik Dergisi, 9(24), 177-191

Keçicioğlu, Y. (2020). Sosyal bilgiler öğretmenlerinin empatik eğilimleri ile çatışma çözme becerilerinin incelenmesi. Yayımlanmamış Yüksek Lisans Tezi. Uludağ Üniversitesi, Bursa.

Koç, A. (2019). İmam hatip lisesi öğretmenlerinin örgütsel güven algıları. Türkiye Din Eğitimi Araştırmaları Dergisi, O(8), 27-55. https://dergipark.org.tr/tr/download/article-file/907830

Koç, A., \& Bastas, M. (2019). The evaluation of the project school model in terms of organizational sustainability and Its effect on teachers' organizational commitment. Sustainability, 11(13), 3549. https://doi.org/10.3390/su11133549

Kula, S. S., \& Akbulut, Ö. F. (2020). Öğretmen adaylarının çocuğa yönelik şiddete ilişkin duyarlıkları ile empatik eğilimleri arasındaki ilişki. Trakya Eğitim Dergisi, 10(3), 917-932. https://doi.org/10.24315/tred.658597 
Külekçi Akyavuz, E. (2019). Conflict situations teachers experience and their use of conflict management strategies. Hacettepe University Journal of Education, 35(3), 511-515. https://doi.org/10.16986/HUJE.2019056768

Maund, L. (1999). Understanding people and organisations: An introduction to organisational behaviour. Stanley Thornes.

McKinney, B. C., Kelly, L. ve Duran, R. L. (1997). The relationship between conflict message styles and dimensions of communication competence. Journal Communication Reports, 10(2), 185-196.

Msila, V. (2019). School managers and conflict management: a case study of a South African primary school. The International Journal of Organizational Diversity, 19(1), 63-75. https://doi.org/10.18848/2328-6261/CGP/v19i01/6375

Oktay, A., \& Yurdunkulu, A. (2020). illköğretim okulu öğretmenlerinin çatışma durumları ve çatışma yönetimi stratejilerinin incelenmesi (Düzce-merkez örneği). Trakya Eğitim Dergisi, 10(1), 285-302. https://doi.org/10.24315/tred.561001

Özdemir, N. (2018). Okullarda öğretmenlerin yaşadığı çatışma ve çatışma yönetim stilleri. Cumhuriyet Üniversitesi Edebiyat Fakültesi Sosyal Bilimler Dergisi, 42 (2) , 93-116

Özgan, H. (2006). ilköğretim okulu öğretmenlerinin çatışma yönetimi stratejilerinin incelenmesi. Yayımlanmamış Doktora Tezi. Gaziantep Üniversitesi, Gaziantep.

Rahim, A., \& Bonoma, T. V. (1979). Managing organizational conflict: a model for diagnosis and intervention. Psychological Reports, 44(3_suppl), 1323-1344. https://doi.org/10.2466/pr0.1979.44.3c.1323

Rogers, C. R. (1975). Empathetic: An unappreciated way of being. The Cunseling Psychologist, 5(2), 2-10.

Traş, Z., \& Keser, G. (2019). Üniversite öğrencilerinin akılcı olmayan inanç empatik eğilim ve duygusal zekâ düzeyleri arasındaki ilişkinin incelenmesi. MANAS Sosyal Araştırmalar Dergisi, 8(3), 2360-2380.

https://doi.org/10.33206/mjss.525234

Silkü, H., Yalçınkaya, M. (2008). Öğretim elemanlarının çatışma yönetimi stratejilerinin incelenmesi. Ege Üniversitesi iletişim Fakültesi Yeni Düşünceler Hakemli E-Dergisi, (3), 339-356

Şahin, C. (2001). Yurtdışı göçün bireyin psikolojik sağlığı üzerindeki etkisine ilişkin kuramsal bir inceleme. Gazi Üniversitesi Gazi Eğitim Fakültesi Dergisi, 2, 57-67.

Şener, E. K. (2019). Illkokul ve ortaokullarda görevli öğretmenlerin çatışma çözme stilleri, iş ve yaşam doyumlarının incelenmesi. Yayımlanmamış Yüksek Lisans Tezi. Marmara Üniversitesi, İstanbul.

Uysal, C.T. (2012). Resmi ve özel ilköğretim okulu öğretmenlerinin çatışma yönetimi stratejilerinin incelenmesi (İstanbul ili Anadolu yakası örneği). Yayımlanmamış Yüksek Lisans Tezi. Maltepe Üniversitesi, İstanbul.

Üstüner, M. \& Kış, A. (2014). İletişim yeterliği ile örgütsel çatışma arasındaki ilişki: eğitim denetmenleri başkanlığı üzerine bir araştırma. Eurasian Journal of Educational Research, 56 (56) , 1-22.

https://doi.org/10.14689/ejer.2014.56.5

Yaman, E., ve Türker, S. (2011). İlköğretim öğretmenlerinin çatışma yönetim stratejileri ve öfke ifade düzeyleri arasındaki ilişki. Akademik Bakış Dergisi, 23(1), 1-11.

Yasmin, K. \& Aleya. (2017). Workplace conflicts: Classifications, causes and management strategies, International Journal of Academic Research and Development, 2(4), 210-216.

Received: 31 May 2021 | Accepted: 22 July 2021 | Published: 31 July 2021

This is an Open Access article distributed under the terms of the Creative Commons Attribution License, which permits unrestricted use, distribution, and reproduction in any medium, provided the original work is properly cited. 